\title{
THE RIGHT TO PHYSICAL AND MENTAL IMMUNITY IN THE LIGHT OF THE NEW CONSTITUTION OF THE REPUBLIC OF ARMENIA AND MODERN CHALLENGES IN THIS FIELD IN ARMENIA
}

\author{
Narine Tonoyan \\ Faculty of History and Law, Armenian State Pedagogical University
}

TONOYAN, N. The Right to Physical and Mental Immunity in the Light of the New Constitution of the Republic of Armenia and Modern Challenges in This Field in Armenia. Bratislava Law Review, Vol. 3, No. 2 (2019), pp. 84 - 90. ISSN 2585-7088, eISSN: 2644-6359

\begin{abstract}
The Constitution of the Republic of Armenia (RA) for the first time envisaged the right to physical and mental immunity (in the former edition of personal immunity) in 2015. According to Article 25(1) of the RA Constitution, everyone shall have the right to physical and mental integrity. That right may be restricted only by law, for the purpose of state security, preventing or disclosing crimes, protecting public order, health and morals or the basic rights and freedoms of others. The bodily rights of the person, including the right to physical and mental immunity, are recognized in professional literature as somatic rights that have become a subject of vigorous debates as a new generation of human rights. In general, human somatic (bodily) rights constitute a wholeness, which includes: the right to life; the right to die or the right to choose a way of giving up one's life (right to suicide, right to use euthanasia), etc. Current report in the light of the RA Constitution report discuss some of important issues in this field: eugenic experiments, medical intervention, organs and tissues transplantation, etc.
\end{abstract}

Key words: constitution, human right, a person is the highest value, human somatic rights constitute, Armenian law, human rights.

\section{INTRODUCTION}

The Armenian Constitution (RA Constitution) for the first time envisaged the right to physical and mental immunity (in the former edition of personal immunity) in 2015. According to Part 1 Article 25 of the RA Constitution, everyone shall have the right to physical and mental integrity. That right may be restricted only by law, for the purpose of state security, preventing or disclosing crimes, protecting public order, health and morals or the basic rights and freedoms of others. Part 3 of Article 25 of the RA Constitution especially underlines: in the fields of medicine and biology, eugenic practices, making the human organs and tissues a source of financial gain, the reproductive cloning of a human being shall be particularly prohibited, and part 4 said: no one may be subjected to scientific, medical or other experiments without his or her freely and clearly expressed consent. The person shall be priorly informed about the potential consequences of such experiments.

The bodily rights of the person, including the right to physical and mental immunity, are recognized in professional literature as somatic rights that have become a subject of vigorous debates as 
a new generation of human rights. In general, human somatic (bodily) rights constitute a wholeness, which includes: the right to life (to live); the right to die (right to peaceful and dignified death) or the right to choose a way of giving up one's life (right to suicide, right to use euthanasia); the right to transplant and clot the parts of human body, organs, tissues (medical cloning); the right to medical intervention; the right to Sexuality, etc.

The constitutional guarantee of the right to physical and mental immunity in the RA will give a new impetus to the protection of this right, however there should be cautious and balanced approach to innovations, their application and their legal regulations, avoiding the mistakes that have already been known to mankind. Some manifestations of physical and mental immunity, assault and other forms of violence, torture, etc. have long been known both by national practice and specialized literature, but some manifestations, in particular, violations of the transplantation, eugenic experiments, need serious study.

Everyone should feel safe and secure in the legal state, and no one can directly or indirectly violate his or her physical and mental integrity, for example, by taking advantage out of the lack of knowledge, low legal awareness, vulnerability or other circumstances that have a significant impact on the person's weighted and comprehensive expression of will.

\section{RECOGNATION OF PHYSICAL AND MENTAL IMMUNITY OF PERSON}

The fact that a person is the highest value and must be protected in all situations is indisputable. The Constitution of the Republic of Armenia (further - the RA Constitution) for the first time envisaged the right to physical and mental immunity (in the former edition of personal immunity) in 2015, thus establishing the separation of the physical and mental immunity of the person and the creation of constitutional guarantees.

In general, as a matter of law, a human is a person, a subject of legal relations. For example, we call the conceived creature embryo up to 12 weeks (0-12 weeks), after which the fetus (12 weeks maximum 9 months), and from the moment of the birth becomes a newborn, human. Therefore, for the category of "human" is important that the subject to be in the material world, to live, which starts from the moment of the birth, coming out of the light and ends with the death of a human brain. However, a man is primarily a biological creature, which is expressed by his physiology, and only afterwards a social being, which is expressed by humanmentality, communication, and worldview.

According to Part 1 Article 25 of the RA Constitution, everyone shall have the right to physical and mental integrity. That right may be restricted only by law, for the purpose of state security, preventing or disclosing crimes, protecting public order, health and morals or the basic rights and freedoms of others.

Part 3 of Article 25 of the RA Constitution especially underlines: in the fields of medicine and biology, eugenic practices, making the human organs and tissues a source of financial gain, the reproductive cloning of a human being shall be particularly prohibited, and part 4 said: no one may be subjected to scientific, medical or other experiments without his or her freely and clearly expressed consent. The person shall be priorly informed about the potential consequences of such experiments.

The bodily rights of the person, including the right to physical and mental immunity, are recognized in professional literature as somatic rights that have become a subject of vigorous debates 
as a new generation of human rights. V.I. Kruss fairly mentions that somatic rights in the existing classification system of human rights and freedoms, due to their peculiarities, cannot be viewed positive in the same line with social rights. Somatic rights are called to protect the physical and spiritual integrity of a person. ${ }^{1}$

These rights are the result of the development of the rights-making and are presented as human rights for the fourth generation. ${ }^{2}$

In general, human somatic (bodily) rights constitute a wholeness, which includes:

1. The right to life (to live)

2. The right to die (right to peaceful and dignified death) or the right to choose a way of giving up one's life (right to suicide, right to use euthanasia);

3. The right to transplant and clot the parts of human body, organs, tissues (medical cloning);

4. The right to gene change;

5. The right to change the appearance (including the right to aesthetic surgery);

6. The right to use narcotic drugs and psychotropic substances,

7. The right to medical intervention;

8. The right to Sexuality,

9. The reproductive right (artificial insemination, right to fertilization, extragenital, test-fertilization and embryo), including abortion,

10. The right of sterilization (stamping, sterilization, correction)

11. Other somatic rights. ${ }^{3}$

\section{THE PROBLEM OF MENDICAL INTERFERENCE IN PHYSICAL AND MENTAL INTEGRITY}

As it is noted in the RA Constitution, two modes of interference in physical and mental integrity should be separated:

1. by the consent of the person,

2. in the cases prescribed by law, proceeding from public interest or excessive necessity.

Having examined the essence of the person's agreement in the field of medical intervention, it should be noted that a part of this agreement also includes the right of the patient to refuse interference, but in this case the latter should be informed of the possible negative consequences of non-use of the intervention. This is the situation when a person, having a necessity for medical intervention, refuses it as his or her subjective right. As the lawyer M. Marchenko, the subjective rights of a human being are the possibilities within the immediate possession of a human being, which can be used or ignored as the means of achieving their own goals. ${ }^{4}$

1 KRUSS, V. Personal ("somatic") rights of a person in the constitutional and philosophical-juridical measure: to the problem’s set. In State and law, 2000, № 10, p. 43 (in Russian).

2 In juridical literature there are different systems of classifying human rights, f.e. classical (State negative obligation) and social rights (State positive obligation), collective and individual rights, rights and freedoms, civil and political (first generation) rights, social, economical and cultural rights (second generation), people, collective rights (third generation), (MOROZOVA, L. Theory of the state and law. $4^{\text {th }}$ edition. Moscow, 2012, p. 146 (in Russian)).

3 This report will only discuss some rights based on the time restrictions.

4 MARCHENKO, M. Tendencies of law development in the modern world. In Moscow, 2015, p. 40 - 41 (in Russian). 
The physician is obliged to inform the patient about his/her health condition, objectives and results of the medical examination, as well as possible risks. ${ }^{5}$

In the light of the RA Constitution it is obvious that if a person on his death refuses the medical intervention while realizing all the results of its absence or he/she utters his/her wish to die, thus no one, including doctors, can force him to be cured. In this regard, no exceptions should be done, however, the cases if the person is unable to express his will, then the intervention will be implemented as the main guarantee of health and life.

However, it should be stated that the consent of a person within the scope of medical intervention may also not be the starting point, that is, the autonomy of a person does not imply that he/ she can receive any treatment that he/ she requires. Here, the physician may limit that desire based on the medical ethics, the available treatment modalities, and the patient's best interests within a reasonable balance.

The regulation on the immunity of organs and tissues are also notable. Nowadays, many countries prohibit buying and selling organs, moreover, there is a criminal liability for it, consequently in a situation where a person has sold his kidney and the other has bought it, there is a crime.

Transplantation is the replacement of tissues or organs that are missing or damaged by tissues or organs taken from their own or other organism.

In the context of the legal relationships of transplantion, we may occasionally encounter such issues that are not the problems deriving from the nature of transplantion, but the issues that may arise from the sale of transplant rights, such as racial collision. As an example there is the case when a white man has been transplanted into a black man heart, and the man's life could be saved, but the man complained because he preferred to die rather than a black man heart transplant. We believe that in such situations, priority should be given to the patient's wishes, if any, and whether there is no wish or that wish exists but is not clear or realistic, the priority should be given to the general principles of the transplantion.

Decision No. 913 of 14. 09. 2010 of the RA Constitutional Court is interesting on this matter: according to which Article 7 of the RA Law "Human Organs and/ or Tissue Transplantation" is called contrary to the RA Constitution on the bases that is to apply the law a number of sublegislative acts are required that have not been adopted yet. Moreover, the removal of the donor material from the dead body can be performed in two ways: either accordingly to his lifetime agreement or to his/her close relatives' agreement posthumously, as well as to the mute agreement.

Being consistent with the above-mentioned position of the RA Constitutional Court, it should be noted that according to Article 7 of the RA Law on "Human Organs and/ or Tissue Transplantation", in one case the principle of alleged consent it is legitimate the obtaining a donor material from the corpse, if during his lifetime, he did not express a desire not to receive donor material during his lifetime), and in the other case, besides the alleged agreement, the consent of the close relatives (relatives) of the deceased donor is also essential.

For the first time in the text of the RA Constitution the term "eugenics" ${ }^{6}$ has been used. In general, the constitutional prohibition on the use of eugenic experiments is to curb scientific or political suspicious goals for the research of the population genetic foundation, as well as the selection of genetic norms.

5 DAVTYAN, S. Bioethics. Yerevan State Medical University. Yerevan, 2009, p. 83 (in Armenian).

6 Eugenics (Greek - noble, dynasty) is a teaching about the improvement of human nature in a biological way. 
Eugenics is a study of the human hereditary health, as well as the improvement of hereditary properties that are solved within the framework of genetic engineering in the modern world. ${ }^{7}$

There are two eugenical manifestations - positive and negative. In the case of the positive one, it is aimed at the development of human abilities, physical abilities, improvement of human health, and the negative attitude directs towards the elimination of inherited defects in human beings.

Negative examples of eugenic manifestations are in the 20th century the Nazi Germany's act, ethnic cleansing in Rwanda, resulting in the genocide. Moreover, sometimes there are also pessimists who consider scientific and technological progress only from a negative point of view, indicating that biotechnology has a negative impact on the following objects such as: genomics, genetically modified organisms, molecular medicine, biochemistry, eugenics, ecogenetics, human biomedical research. ${ }^{8}$ It is necessary to understand one simple truth that any phenomenon has its positive and negative aspects, consequently the problem here is not to prohibit the phenomenon, but to use it correctly. Simultaneously, let's discuss the issue of creating an atomic bomb. From a scientific point of view it is often discussed whether the creation of an atomic bomb is destructive or peaceful. Today, it has restraining, peace-loving nature, since at least two states have it, but they do not apply, given the likelihood of using that bomb on the other side as well. At the same time, if we examine the history of the creation of the bomb, we will see that from the very beginning it was called a horrible, destructive phenomenon. That is to say, the problem is that it is necessary to set up clear mechanisms of use and to provide legal resurrection.

As it is truly was indicated in Armenian literature, the mentioned norm of the RA Constitution will bring to the agenda of the RA legal system, particularly the following issues:

1. Discussions on the signing and ratification of the Convention on Human and Biomedicine (Ovidium Convention).

2. Study of the constitutional concept of "eugenical experiments" and clarification of borders. First of all, the RA Constitution prohibits not only the activities of eugenics, but also the experiments, while a number of methods of population selection have already passed the purely test phase and are independent activities. Secondly, negative eugenics (genetic medical intervention of a specific person, with the aim of eliminating the incurable diseases) and positive eugenics (biotechnological intervention of human heredity, with the aim to selectively change of its "genetic sort") is distinguished. Moralists note that the first eugenics is generally welcomed, and the latter gives rise to doubts and objections. ${ }^{9}$

3. The systematic review of the current legislation in the context of the constitutional prohibition on the Eugenics, in particular, the study and clarification of the selection and choice of donor seeds for the purpose of voluntary medical malnutrition and artificial (experimental) excretion, as provided for by the RA Law on Human Reproductive Health and Reproductive Rights. It should be born in mind that the type of eugenics is the choice of human choice by gender, as well as the removal of reproductive people from the ill or socially unwanted gene pool.

7 KUSHERBAYEV, S. Medical-juridical aspects of gene engineering. In Eurasian juridical journal, N 8, Velikey Novgorod, 2010, p. 98 (in Russian).

8 BAKSANSKEY, O., GNATIK, E., KUCHER, E. Nanotechnologies, biomedicine, philosophy of education in the mirror of interdisciplinary context. In Moscow, 2010, p. 150 - 160 (in Russian).

9 KUCHEROV, I. Modern biotechnologies: social-aesthetical aspects. The autoreferat for the PhD dissertation. In Moscow, 2006, p. 5 (in Russian). 
4. Eugenic experiments, reproductive cloning of human beings, the use of reproductive technologies to plan the future gender of the child, and the provision of other socially dangerous acts in the field of bioethics as independent crimes in the RA Criminal Code. ${ }^{10}$

In general, the cautiousness towards genetic changes is accelerating in Armenia under the light of Article 25 of the RA Constitution. Gene alteration is the situation when, for example, a person is getting prenatal testing to exercise reproductive rights to check the future baby's possible deviations, so in result of changes the future child will get rid of a number of diseased phenomena. Sometimes it is called pronation. ${ }^{11}$

The genetic engineering is a combination of methods and approaches that are intended to create biological structures. Genetic engineering examines the changes in the sex cells related to the body's new form and nature. ${ }^{12}$ It should be noted that the right to genetic change is a possibility for a person to carry out a genetic change at his own risk, which, first of all, is aimed at the elimination of genetic defects. It will only create a favorable environment for improving the quality of human life as it will be possible to avoid or get rid of a number of illnesses and pathological states. At the same time, it is necessary to set up clear legal mechanisms to pay close attention to the issue of scientific and practical research.

There are plenty of controversial and debated issues about the right of physical and mental immunity, as it is linked to the highest value, which is the human.

It can be argued further in the context of physical and mental immunity, however it should be noted that in the countries where the population is not large (as of January 1,2018, the population in Armenia is $2,972,900^{13}$ ), this issue is more acute is in the context of security, national security and independence of the state.

The average age of the permanent population as of the beginning of 2017 year was 36.2 (35.9 years in 2016), 34.3 for men $\left(2016,34.1\right.$ ), and for women - 38.0 (in 2016, 37.6). ${ }^{14}$ The aging of the population also focuses on the protection of physical and mental immunity.

\section{CONCLUSION}

Summarizing the report, it can be noted that the constitutional guarantee of the right to physical and mental immunity in the Republic of Armenia will give a new impetus to the protection of this right, however there should be cautious and balanced approach to innovations, their application and their legal regulations, avoiding the mistakes that have already been known to mankind.

Some manifestations of physical and mental immunity, assault and other forms of violence, torture, etc. have long been known both by national practice and specialized literature, but some

10 GAMBARYAN, A. The horizons of the development of jurisprudence and bioaesphetics in the 21-st century. The system of biojuridacy, the biomedical and ethical, juridical issues. The collection of materials of republican scientific conference. Armenian-Russian (Slavonic) University, Yerevan State Medical University. Yerevan, 2016, p. 26 - 27 (in Armenian).

In the circle of child planning pregnancy before the child's planning is either a woman or a man subjected to genetic testing to check whether he or she has a disease or has a premature illness that may hinder the development of the fetus (or the baby will be born with defects), in other words, there are negative phenomena or addiction to such phenomena.

12 KUSHERBAYEV, S. Medical-juridical aspects of gene engineering. In Eurasian juridical journal, N 8, Velikey Novgorod, 2010, p. 97 (in Russian).

13 http://armstat.am/file/article/sv_12_17a_520.pdf, p. 137:

14 Ibid., p. 138. 
manifestations, in particular, violations of the transplantation, eugenic experiments, need serious study.

Everyone should feel safe and secure in the legal state, and no one can directly or indirectly violate his or her physical and mental integrity, for example, by taking advantage out of the lack of knowladge, low legal awareness, vulnerability or other circumstances that have a significant impact on the person's weighted and comprehensive expression of will.

The performed study is a cornerstone for the study of the human in the context of both legal and biological unity.

\section{Bibliography:}

BAKSANSKEY, O., GNATIK, E., KUCHER, E. Nanotechnologies, biomedicine, philosophy of education in the mirror of interdisciplinary context. In Moscow, 2010 (in Russian).

DAVTYAN, S. Bioethics. Yerevan State Medical University. Yerevan, 2009 (in Armenian)

GAMBARYAN, A. The horizons of the development of jurisprudence and bioaesphetics in the 21-st century. The system of biojuridacy, the biomedical and ethical, juridical issues. The collection of materials of republican scientific conference. Armenian-Russian (Slavonic) University, Yerevan State Medical University. Yerevan, 2016 (in Armenian).

KRUSS, V. Personal ("somatic") rights of a person in the constitutional and philosophical-juridical measure: to the problem’s set. In State and law, 2000, № 10 (in Russian).

KUCHEROV, I. Modern biotechnologies: social-aesthetical aspects. The autoreferat for the PhD dissertation. In Moscow, 2006 (in Russian).

KUSHERBAYEV, S. Medical-juridical aspects of gene engineering. In Eurasian juridical journal, N 8, Velikey Novgorod, 2010 (in Russian).

MARCHENKO, M. Tendencies of law development in the modern world. Moscow. 2015 (in Russian).

MOROZOVA, L. Theory of the state and law. 4-th edition. Moscow, 2012 (in Russian).

\section{Contact information:}

Narine Tonoyan, Ph.D in law, Associate professor

e-mail: narinetonoyan18@aspu.am, tnarik@rambler.ru

Armenian State Pedagogical University

Faculty of History and Law

17 Tigran Mets ave. 0010

Yerevan

Armenia 